Open Access

\title{
Oxygen carrying capacity of salvaged blood in patients undergoing off-pump coronary artery bypass grafting surgery: a prospective observational study
}

Xiu Liang Li ${ }^{1}$, Peng Dong ${ }^{2}$, Ming Tian², Jia Xiang $\mathrm{Ni}^{{ }^{* *}}$ and Fang Gao Smith ${ }^{3,4^{*}}$

\begin{abstract}
Background: Intraoperative cell salvage (ICS), hereby referred to 'mechanical red cell salvage', has been widely used and proven to be an effective way to reduce or avoid the need for allogeneic red blood cells (RBCs)transfusion and its associated complications in surgeries involving major blood loss. However, little is known about the influence of this technique on the functional state of salvaged RBCs. Furthermore, there are no articles that describe the change of free hemoglobin ( $\mathrm{fHb}$ ) in salvage blood during storage, which is a key index of the quality control of salvaged blood. Therefore, in this study, the influence of ICS on the function of salvaged RBCs and the changes of salvaged RBCs during storage were studied with respect to the presence of oxyhemoglobin affinity (recorded as a $\mathrm{P}_{50}$ value) and the level of 2, 3-diphosphoglycerate (2, 3-DPG) and fHb by comparing salvaged RBCs with self-venous RBCs and 2-week-old packed RBCs.
\end{abstract}

Methods: Fifteen patients undergoing off-pump coronary artery bypass grafting (OPCAB) surgery were enrolled. Blood was collected and processed using a Dideco Electa device. The level of $\mathrm{P}_{50}, 2,3-\mathrm{DPG}$ and fHB from salvaged RBCs, venous RBCs and 2-week-old packed RBCs was measured. We also measured the changes of these indicators among salvaged RBCs at $4 \mathrm{~h}$ (storage at $21-24^{\circ} \mathrm{C}$ ) and at $24 \mathrm{~h}$ (storage at $1-6^{\circ} \mathrm{C}$ ).

Results: The $P_{50}$ value of salvaged RBCs at $0 \mathrm{~h}(28.77 \pm 0.27 \mathrm{mmHg})$ was significantly higher than the value of venous RBCs $(27.07 \pm 0.23 \mathrm{mmHg}, p=0.000)$ and the value of the 2-week-old packed RBCs $(16.26 \pm$ $0.62 \mathrm{mmHg}, p=0.000)$. $P_{50}$ value did not change obviously at $4 \mathrm{~h}(p=0.121)$ and $24 \mathrm{~h}(p=0.384)$ compared with the value at $0 \mathrm{~h}$. The 2, 3-DPG value of salvaged RBCs at $0 \mathrm{~h}(17.94 \pm 6.91 \mu \mathrm{mol} / \mathrm{g} \mathrm{Hb})$ was significantly higher than the value of venous RBCs $(12.73 \pm 6.52 \mathrm{mmHg}, p=0.007)$ and the value of the 2 -week-old packed RBCs $(2.62 \pm$ $3.13 \mathrm{mmHg}, p=0.000)$. The level of $2,3-\mathrm{DPG}$ slightly decreased at $4 \mathrm{~h}(p=0.380)$ and $24 \mathrm{~h}(p=0.425)$ compared with the value at $0 \mathrm{~h}$. Percentage of hemolysis of the salvaged blood at $0 \mathrm{~h}(0.51 \pm 0.27 \%)$ was significantly higher than the level of venous blood $(0.07 \pm 0.05 \%, p=0.000)$ and the value of 2-week-old packed RBCs $(0.07 \pm 0.05 \%, p=0.000)$, and reached $1.11 \pm 0.42 \%$ at $4 \mathrm{~h}(p=0.002)$ and $1.83 \pm 0.77 \%$ at $24 \mathrm{~h}(p=0.000)$.

Conclusions: The oxygen transport function of salvaged RBCs at $0 \mathrm{~h}$ was not influenced by the cell salvage process and was better than that of the venous RBCs and 2-week-old packed RBCs. At the end of storage, the oxygen transport function of salvaged RBCs did not change obviously, but percentage of hemolysis significantly increased.

Keywords: Intraoperative cell salvage, Oxyhemoglobin affinity, 2,3-disphosphoglycerate, Free hemoglobin

\footnotetext{
* Correspondence: nijiaxiang@263.net; f.g.smith@bham.ac.uk

'Department of Pain Management, Xuanwu Hospital of Capital Medical

University, No. 45, Changchun Street, Xicheng District, 100053 Beijing, China

${ }^{3}$ Department of Anaesthesiology, the 2nd Affiliated Hospital \& Yuying

Children Hospital of Wenzhou Medical University, Wenzhou, China

Full list of author information is available at the end of the article
} 


\section{Background}

Currently, increasing recognition of the morbidity and mortality associated with allogeneic RBCs transfusion in patients undergoing coronary artery bypass grafting $(\mathrm{CABG})$ surgery has gained increasing attention in clinical setting [1-3]. Moreover, shortages of allogeneic RBCs have become a challenge for surgeries involving major blood loss. ICS as a blood conservation technique has been widely used and proven to be an effective way to reduce or avoid the need for allogeneic RBCs transfusion and its associated complications in cardiac surgery, orthopedic surgery, liver transplantation and neurosurgery [4-8]. However, little is known about the influence of this cell-saving technique on the functional state of salvaged RBCs, especially on the oxygen carrying capacity and their contents of 2, 3-DPG. Falling levels of red cell 2, 3DPG resulting in the increase in oxygen affinity and the left shift of hemoglobin oxygen dissociation curve (HODC) can influence the oxygen from RBCs to body tissues $[9,10]$. Furthermore, the level of $\mathrm{fHb}$, as a measure of hemolysis, is a key index of the quality control of stored RBCs, and associated with renal dysfunction and an increased risk of death [11-14]. There are no articles that describe the effect of storage time on the level of $\mathrm{fHb}$ in salvage blood (at room temperature $21-24{ }^{\circ} \mathrm{C}$ for up to $4 \mathrm{~h}$ and at $1-6^{\circ} \mathrm{C}$ for up to $24 \mathrm{~h}$ ) [15].

Therefore, firstly, the aim of the present study was to examine how in vitro the cell salvage procedure influences $\mathrm{P}_{50}$ value as well as the 2, 3-DPG contents by comparing salvaged RBCs with self-venous RBCs and 2-week-old packed RBCs. Secondly, this study also was aimed to observe the changes of $\mathrm{fHb}, \mathrm{P}_{50}$ and 2, 3-DPG during storage; the results from our study may provide a basis for the safe use of salvaged RBCs in the clinical setting.

\section{Methods}

\section{Study participants}

This study was approved by the local Institutional Review Board of the Beijing Friendship Hospital. After written informed consent was obtained, 15 Patients scheduled for OPCAB surgery were enrolled. An $\mathrm{OPCAB}$ surgery is a procedure that does not require the use of the cardiopulmonary bypass $(\mathrm{CPB})$ machine [16]. Exclusion criteria were patients less than 18 years or over 80 years old, emergency operation, hematopathy, the use of $\mathrm{CPB}$, preoperative and intraoperative allogeneic RBCs transfusion. All patients were operated by one group surgeons. We used the Dideco Electa autotransfusion device in all patients because the function of washed erythrocytes differs widely from one device to another [17].

\section{Cell salvage procedures}

The Dideco Electa device (SN: BO15214H05, 42037 Mirandola Italy) was set up and run according to the manufacturer's instructions. We selected the automatic mode and used a BT225-mL bowl operated with a centrifuge speed of $5600 \mathrm{rpm}$. The bowl filled at a speed of $400 \mathrm{ml} / \mathrm{min}$, washed at rate of $500 \mathrm{ml} / \mathrm{min}$ with a wash volume of $1000 \mathrm{ml}$ and emptied at a speed $400 \mathrm{ml} / \mathrm{min}$. The fill, wash and empty rates were strictly followed to maintain consistency between samples. The blood was heparinized with $0.9 \%$ saline (30 000 IU of heparin in $1000 \mathrm{~mL}$ of $0.9 \%$ saline) and washed also with $0.9 \%$ saline $[18,19]$. Before blood collection, vacuum suction was limited to -0.2 bar to prevent excessive hemolysis, the suction line and the reservoir were rinsed with $150 \mathrm{ml}$ of $0.9 \%$ heparinized saline and during collection the heparinized solutions were added to the blood in a ratio of approximately 1:7. One trained executive operator accomplished all the blood salvage process.

\section{Blood sample collection}

All blood samples were taken, respectively, from the central venous line after induction of anesthesia, from the reinfusion bag at $0 \mathrm{~h}, 4 \mathrm{~h}$ (storage at $21-24{ }^{\circ} \mathrm{C}$ ) and $24 \mathrm{~h}$ (storage at $1-6{ }^{\circ} \mathrm{C}$ ) for the measurement of $\mathrm{P}_{50}, 2$, 3-DPG, fHb and blood gas analysis. Blood samples were also drawn from 2-week-old packed RBCs which were supplied by blood bank of Beijing Friendship Hospital and had been stored for 2 weeks at $1-6{ }^{\circ} \mathrm{C}$. Packed RBCs were prepared by whole bloods which were centrifuged for $7 \mathrm{~min}$ with a centrifugal force of $5000 \times$ g at $4 \pm 2{ }^{\circ} \mathrm{C}$, and were added with acid-citrate-dextrose solution (citrate $4.8 \mathrm{~g} / \mathrm{L}$, sodium citrate $13.2 \mathrm{~g} / \mathrm{L}$ and dextrose $14.7 \mathrm{~g} / \mathrm{L})$. Packed RBCs were not leukocyte-reduced and washed. All blood samples were analyzed within $20 \mathrm{~min}$ after collection by one person.

\section{Laboratory measurements \\ Free hemoglobin}

The fHb was measured with the HemoCue Plasma Low/ $\mathrm{Hb}$ Photometer (HemoCue, Inc., Angelholm, Sweden) which is a sensitive test method and can detect down to $0.0 \mathrm{~g} / \mathrm{dl}[11]$. Hb concentrations were measured using a HemoCue Hb 201 + Analyzer (Kuvettgatan1, Angelholm, Sweden). The percentage of hemolysis was calculated using the following formula: Percentage of hemolysis $(\%)=[(1-\mathrm{Hct}) \times \mathrm{fHb} / \mathrm{Hb}] \times 100 \%[20]$.

\section{Determination of $P_{50}$}

Hemoglobin Oxygen dissociation curve were performed by the method of Opdahl $\mathrm{H}$ [21]. In brief, the blood samples were divided into two $5 \mathrm{~mL}$ plastic syringes (2.0 mL each) which were equilibrated with a gas containing $5 \% \mathrm{CO}_{2}$ and $20 \% \mathrm{O}_{2}$ in nitrogen or $5 \% \mathrm{CO}_{2}$ 
in nitrogen, respectively, for $20 \mathrm{~min}$. The samples of the two syringes were then transferred anaerobically into $2 \mathrm{~mL}$ syringes containing a glass bead for blood gas analysis. The measured $\mathrm{PO}_{2}$ was corrected for standard conditions ( $\mathrm{pH} 7.4$, temperature $37{ }^{\circ} \mathrm{C}, \mathrm{PaCO}_{2} 40 \mathrm{mmHg}$ ) according to the equation: $\triangle \log \mathrm{PO}_{2}=-0.48 \Delta \mathrm{pH}+0.0013 \mathrm{BE}+$ $0.024 \triangle \mathrm{T}$ [22]. HODC was drawn from five to seven sets of corresponding $\mathrm{SO}_{2}-\mathrm{PO}_{2}$ values.

The sigmoid $\mathrm{HbO}_{2}$ dissociation curve was converted to a rectilinear one according to the Hill equation which is approximately valid in the range 30 to $70 \% \mathrm{SO} 2: \log$ $[\mathrm{Y} /(100-\mathrm{Y})]=\log \mathrm{K}+\mathrm{n} \log \mathrm{P}$, where $\mathrm{Y}$ is oxygen saturation, $\mathrm{K}$ is the equilibrium constant for the combination of $\mathrm{O}_{2}$ with $\mathrm{Hb}, \mathrm{n}$ is an expression of "heme-heme interaction" and $\mathrm{P}$ is the $\mathrm{PO}_{2}$ value at which $\mathrm{Y}$ is measured $[23,24]$. When the data are plotted in this way, a straight line is obtained; $\mathrm{n}$ is determined by the slope of the line; $\mathrm{P}_{50}$ which is the $\mathrm{PO}_{2}$ corresponding to half saturation of the $\mathrm{Hb}$ with oxygen is obtained from the intercept of the line at the abscissa log $[\mathrm{Y} /(100-\mathrm{Y})]=0[10]$.

The 2, 3 DPG was measured by Ultraviolet test according to the manufacturer's instructions (Roche Diagnostics GmbH, Mannheim, Germany). Plasma sodium, potassium, calcium, lactate and Chloride concentrations were assayed in the GEM Premier 3000 Blood Gas/Electrolyte Analyzer (Instrumentation Laboratory Company, 101 Hartwell Avenue Lexington, Massachusetts, USA).

\section{Statistical analysis}

Data were analyzed using SPSS15.0 for Windows (SPSS, Inc., Chicago, USA) and presented as mean \pm SD. The differences between venous RBCs and salvaged RBCs were analyzed using paired-samples $T$ test. The differences between 2-week-old packed RBCs and venous RBCs, salvaged RBCs were analyzed using independentsamples $T$ test. The changes during the storage of salvaged RBCs were analyzed using one-way analysis of variance (ANOVA). When ANOVA indicated that effects were significant, post hoc analysis was performed using the LSD approach. $P<0.05$ was considered statistically significant.

\section{Results}

From August 2013 to February 2014, fifteen eligible patients were enrolled in this study. They were men and the mean age was $62.3 \pm 8.5$ (ranging from 51 to 76 years).

\section{The change of $P_{50}$ level and 2, 3-DPG level}

The change of $\mathrm{P}_{50}$ level and 2, 3-DPG level was presented in Table 1.

The $\mathrm{P}_{50}$ level of venous RBCs and salvaged RBCs $0 \mathrm{~h}$, $4 \mathrm{~h}, 24 \mathrm{~h}$ and 2-week-old packed RBCs was, respectively,
Table $1 \mathrm{P}_{50}$ level and 2, 3-DPG level

\begin{tabular}{rcc}
\hline & $P_{50}(\mathrm{mmHg})$ & 2, 3-DPG $(\mu \mathrm{mol} / \mathrm{g} \mathrm{Hb})$ \\
\hline salvaged RBCs 0 h & $27.07 \pm 0.23$ & $12.73 \pm 6.52$ \\
salvaged RBCs 4 h & $28.77 \pm 0.27$ & $17.94 \pm 6.91$ \\
salvaged RBCs 24 h & $28.94 \pm 0.25$ & $15.17 \pm 11.61$ \\
venous RBCs & $28.87 \pm 0.34$ & $15.38 \pm 5.85$ \\
2-week-old packed RBCs & $16.26 \pm 0.62$ & $2.62 \pm 3.13$ \\
\hline
\end{tabular}

$27.07 \pm 0.23,28.77 \pm 0.27,28.94 \pm 0.25,28.87 \pm 0.34$ and $16.26 \pm 0.62 \mathrm{mmHg}$. There was thus general increase in $\mathrm{P}_{50}$ level at salvaged RBCs, the increase at $0 \mathrm{~h}, 4 \mathrm{~h}$ and $24 \mathrm{~h}$ was significant compared with the $\mathrm{P}_{50}$ level at venous $\operatorname{RBCs}(p=0.000$, respectively), and the increase at $0 \mathrm{~h}, 4 \mathrm{~h}$ and $24 \mathrm{~h}$ was also significant compared with the $\mathrm{P}_{50}$ level at 2-week-old packed RBCs $(p=0.000$, respectively). $\mathrm{P}_{50}$ value did not change obviously at $4 \mathrm{~h}$ $(p=0.121)$ and $24 \mathrm{~h}(p=0.384)$ compared with the value at $0 \mathrm{~h}$.

The 2, 3-DPG level of venous RBCs and salvaged RBCs $0 \mathrm{~h}, 4 \mathrm{~h}, 24 \mathrm{~h}$ and 2-week-old packed RBCs was, respectively, $12.73 \pm 6.52, \quad 17.94 \pm 6.91, \quad 15.17 \pm 11.61$, $15.38 \pm 5.85$ and $2.62 \pm 3.13 \mu \mathrm{mol} / \mathrm{g} \mathrm{Hb}$. There was thus general increase in 2, 3-DPG level at salvaged RBCs, the increase was significant at $0 \mathrm{~h}(p=0.007)$, and not significant at $4 \mathrm{~h}(p=0.272)$ and at $24 \mathrm{~h}(p=0.099)$ compared with the value of venous RBCs, and the increase at $0 \mathrm{~h}, 4 \mathrm{~h}$ and $24 \mathrm{~h}$ was significant compared with the 2 , 3-DPG level at 2-week-old packed RBCs ( $p=0.000$, respectively). The level of 2, 3-DPG slightly decreased at $4 \mathrm{~h}(p=0.380)$ and $24 \mathrm{~h}(p=0.425)$ compared with the value at $0 \mathrm{~h}$.

\section{The changes of salvaged RBCs during storage}

The changes of salvaged RBCs during storage were presented in Table 2.

The mean $\mathrm{fHB}$ level was $0.12 \pm 0.09 \mathrm{~g} / \mathrm{L}$ in venous RBCs, $0.19 \pm 0.13 \mathrm{~g} / \mathrm{L}$ in 2-week-old packed RBCs, $1.04 \pm 0.52 \mathrm{~g} / \mathrm{L}$ in $0 \mathrm{~h}$ salvaged $\mathrm{RBCs}$ and increased throughout storage time, reached $2.10 \pm 0.74 \mathrm{~g} / \mathrm{L}$ at $4 \mathrm{~h}$ (compared with the value at $0 \mathrm{~h}, p=0.003$ ), $3.69 \pm$ $1.18 \mathrm{~g} / \mathrm{L}$ at $24 \mathrm{~h}$ (compared with the value at $0 \mathrm{~h}$, $p=0.000)$.

The percentage of hemolysis of salvaged RBCs at $0 \mathrm{~h}$ was $0.51 \pm 0.27 \%$, and was significantly higher than the value of venous $\mathrm{RBCs}(0.07 \pm 0.05 \%, p=0.000)$ and the value of 2 -week-old packed RBCs (0.07 \pm $0.05 \%, p=0.000)$, and increased throughout storage time, reached $1.11 \pm 0.42 \%$ at $4 \mathrm{~h}$ (compared with the value at $0 \mathrm{~h}, p=0.002), 1.83 \pm 0.77 \%$ at $24 \mathrm{~h}$ (compared with the value at $0 \mathrm{~h}, p=0.000$ ).

The potassium level was $0.59 \pm 0.26 \mathrm{mmol} / \mathrm{L}$ in $0 \mathrm{~h}$ salvaged RBCs and increased throughout storage time, 
Table 2 Concentration of $\mathrm{fHb}$, percentage of hemolysis, the value of potassium and $\mathrm{pH}$ value

\begin{tabular}{rlccl}
\hline & $f H B(g / L)$ & Percentage of hemolysis (\%) & Potassium $(\mathrm{mmol} / \mathrm{L})$ & $\mathrm{pH}$ \\
\hline salvaged RBCs 0 h & $1.04 \pm 0.52$ & $0.51 \pm 0.27$ & $0.59 \pm 0.26$ & $7.51 \pm 0.07$ \\
salvaged RBCs 4 h & $2.10 \pm 0.74$ & $1.11 \pm 0.42$ & $1.69 \pm 0.38$ & $7.43 \pm 0.05$ \\
salvaged RBCs 24 h & $3.69 \pm 1.18$ & $1.83 \pm 0.77$ & $7.18 \pm 2.53$ & $7.42 \pm 0.08$ \\
venous RBCs & $0.12 \pm 0.09$ & $0.07 \pm 0.05$ & $4.34 \pm 0.37$ & $7.33 \pm 0.06$ \\
2-week-old packed RBCs & $0.19 \pm 0.13$ & $0.07 \pm 0.05$ & $16.56 \pm 3.58$ & $6.50 \pm 0.06$ \\
\hline
\end{tabular}

reached $1.69 \pm 0.38 \mathrm{mmol} / \mathrm{L}$ at $4 \mathrm{~h}$ (compared with the value at $0 \mathrm{~h}, p=0.000), 7.18 \pm 2.53 \mathrm{mmol} / \mathrm{L}$ at $24 \mathrm{~h}$ (compared with the value at $0 \mathrm{~h}, p=0.000$ ). But the potassium level at $4 \mathrm{~h}$ and $24 \mathrm{~h}$ was still lower compared with the value of 2-week-old packed RBCs $(p=0.000$, respectively).

The $\mathrm{pH}$ level in $0 \mathrm{~h}$ salvaged $\mathrm{RBCs}$ was $7.51 \pm 0.07$, decreased throughout storage time and reached $7.43 \pm 0.05$ at $4 \mathrm{~h}$ (compared with the value at $0 \mathrm{~h}, p=0.015$ ) and $7.42 \pm$ 0.08 at $24 \mathrm{~h}$ (compared with the value at $0 \mathrm{~h}, p=0.014$ ). The $\mathrm{pH}$ level at $4 \mathrm{~h}$ and $24 \mathrm{~h}$ was still higher than the value of 2-week-old packed RBCs ( $p=0.000$, respectively).

\section{Discussion}

ICS has become an important autotransfusion method in cardiac surgery and the safe issue also has been extensively studied [4, 5, 25, 26]. However, little attention has been paid to the oxygen transport function of salvaged RBCs which should be the highest priority during salvage. In this preliminary work, we studied the $\mathrm{P}_{50}$ and 2 , 3-DPG level from salvaged RBCs and venous RBCs via a self-control study to determine the influence of the cell salvage process on salvaged RBCs. $\mathrm{P}_{50}$ is widely used as a criterion for assessing the binding affinity of hemoglobin for $\mathrm{O}_{2}$ and 2, 3-DPG is a key substance in regulating the oxygen delivery in vivo [17]. The results showed that the $\mathrm{P}_{50}$ value of salvaged $\mathrm{RBCs}$ at $0 \mathrm{~h}$ significantly increased compared with the value of venous $\mathrm{RBCs}$ and 2 -week-old packed RBCs, and the 2, 3-DPG value also significantly increased compared with the value of venous RBCs and 2-week-old packed RBCs. Thus, the oxygen transport function of salvaged RBCs at $0 \mathrm{~h}$ was not influenced by the cell salvage process and was better than that of venous RBCs and 2-week-old packed RBCs.

The reason why the $P_{50}$ and 2, 3-DPG level increased in salvaged RBCs at $0 \mathrm{~h}$ probably was that the vast majority of salvaged RBCs were young RBCs and old RBCs were eliminated during the operative procedure and the cell salvage progress. Young RBCs have higher $\mathrm{P}_{50}$ and 2, 3-DPG level than old RBCs [9, 10]. Haidas reported that the $\mathrm{P}_{50}$ and 2, 3-DPG level in young RBCs, old $\mathrm{RBCs}$ and total venous RBCs were, respectively, 31.2, 25.1 and $29.3 \mathrm{mmHg}, 17.2,7.3$ and $14.7 \mu \mathrm{mol} / \mathrm{g} \mathrm{Hb}$ [9]. Bunn also reported that the level of 2, 3-DPG in young cells and old cells separated by centrifugation was 17.1 and $12.3 \mu \mathrm{mol} / \mathrm{g} \mathrm{Hb}[10]$. In our study, the $\mathrm{P}_{50}$ and 2, 3DPG level in venous RBCs and $0 \mathrm{~h}$ salvaged RBCs were, respectively, 27.07 and $28.77 \mathrm{mmHg}, 12.73$ and $17.94 \mu \mathrm{mol} / \mathrm{g} \mathrm{Hb}$. These results aligned well with studies of Haidas and Bunn. Furthermore, Che et al. also reported that in salvaged RBCs at $0 \mathrm{~h}$, the 2, 3-DPG level was higher than that of venous RBCs (4.88vs. $4.38 \mathrm{mmol} / \mathrm{L}$, $P<0.05$ ) [20]. However, there are some contrary reports [17, 27]. Gu et al. thought that the high shear stress generated during the cell saver procedure may result in the 2, 3-DPG depletion, from $9.2 \mu \mathrm{mol} / \mathrm{g} \mathrm{Hb}$ in venous $\mathrm{RBCs}$ to $5.41 \mu \mathrm{mol} / \mathrm{g} \mathrm{Hb}$ in the salvaged RBCs [27]. But, cardiopulmonary bypass (CPB) was routinely used in their study and allogeneic RBCs were transfused in 6 patients. CPB can decrease 2, 3-DPG content of RBCs and in our study, the 2, 3-DPG level in 2-week-old packed RBCs had dropped to $2.62 \pm$ $3.13 \mu \mathrm{mol} / \mathrm{g} \mathrm{Hb}(0.0$ in 6 patients) $[28,29]$. So, the use of $\mathrm{CPB}$ and allogeneic RBCs may influence the accuracy of their results and was excluded in our study.

2-week-old packed RBCs often develop storage lesions. Glucose in these RBCs is consumed, levels of DPG and ATP decrease, while potassium levels increase [10, 30, 31]. In our study, 2-week-old packed RBCs also had these changes. Compared with 2-week-old packed RBCs, salvaged RBCs at $0 \mathrm{~h}$ had better oxygen transport function. When 2, 3-DPG-poor RBCs are transfused, only $43.89 \%$ of the final level of 2, 3-DPG is resynthesized within $6 \mathrm{~h}$ after the end of transfusion [32]. Liang also reported that salvaged $\mathrm{RBCs}$ had better morphologic results than 2-week-old packed RBCs [8]. Observational studies in trauma, critical illness and cardiac surgery, linking the administration of allogeneic RBCs to increased mortality, support the concern that transfusion of allogeneic RBCs may be detrimental [1-3, 33-35]. A meta analysis showed that the use of ICS reduced the rate of exposure to allogeneic $\mathrm{RBC}$ transfusion by a relative $38 \%$ and resulted in an average saving of 0.68 units of allogeneic RBC per patient [36]. So in CABG surgery with probable hemorrhage, ICS should as much as possible be used in order to avoid the transfusion of 2, 3DPG-poor allogeneic RBCs.

Measurement of $\mathrm{fHb}$ and percentage of hemolysis has been used as a criterion for the quality control. An 
official guideline for acceptable level of hemolysis for salvaged blood has not been established. However, the quality standard level of hemolysis rate has been referred to packed blood $<1 \%$ in USA or $<0.8 \%$ in Europe [37]. In this study, percentage of hemolysis was $0.51 \pm 0.27 \%$ in salvaged RBCs at $0 \mathrm{~h}$, which was well below $1 \%$ or $0.8 \%$ level. The increase in the level of fHb could be injurious by several potential mechanisms. Firstly, fHb can react with $\mathrm{NO}$ about 1000 times faster than with intact erythrocytes in a near-diffusion limited reaction to inhibit NO signaling and even at concentrations below $10 \mu \mathrm{mmol} / \mathrm{L}$ (in heme)still can produce potent vasoconstriction when infused into the rat circulation [38]. Secondly, when hemoglobin is released into the extracellular compartment, ferrous heme is oxidized to ferryl heme protoporphyrin radical species which are potent oxidants that cause lipid peroxidation. Furthermore, $\mathrm{fHb}$ affinity for $\mathrm{O}_{2}$ is higher than intracorpuscular $\mathrm{Hb}\left(\mathrm{P}_{50}: 20.50\right.$ vs.26.72 $\left.\mathrm{mmHg}, P<0.05\right)$ [10]. In clinical studies, elevated $\mathrm{fHb}$ concentration was independently and significantly correlated with acute kidney injury during major aortic surgery and an increased risk of death in critically ill patients with sepsis [12-14].

In this study, we also studied the changes of salvaged RBCs during storage. $\mathrm{P}_{50}$ level at $4 \mathrm{~h}$ and $24 \mathrm{~h}$ did not change obviously compare to that at $0 \mathrm{~h}$. fHB level significantly increased and reached $2.10 \pm 0.74 \mathrm{~g} / \mathrm{L}$ at $4 \mathrm{~h}$ and $3.69 \pm 1.18 \mathrm{~g} / \mathrm{L}$ at $24 \mathrm{~h}$. The level of potassium also significantly increased at the end of storage. The significant increase in the level of $\mathrm{fHB}$ and potassium was mainly due to the increase in osmotic fragility of salvaged RBCs which resulted in the increase in the susceptibility of RBCs to lysis [39]. In previous studies, cell saver salvaged blood stored at room temperature for $6 \mathrm{~h}$ and at $1-6{ }^{\circ} \mathrm{C}$ for $24 \mathrm{~h}$ after collection was transfused into infants undergoing open heart surgery without any relevant complications [40, 41]. However, these high fHB levels may not be acceptable for patients with endothelial dysfunction. Yu et al. reported that $\mathrm{fHB}$ did not cause systemic hypertension in healthy wild-type mice but induced severe systemic vasoconstriction in mice with endothelial dysfunction [42, 43]. They thought that reduced vascular nitric oxide levels associated with endothelial dysfunction sensitized mice to the vasoconstrictor effects of $\mathrm{fHb}$ administration [43].

Our study had limitations; firstly, we only measured effects of the Dideco Electa device on the quality of salvaged RBCs in patients undergoing OPCAB surgery, however the quality of washed RBCs is affected by the operative procedure and the type of device [17, 44]. Secondly, the study had a small sample size which may result in higher standard deviation of 2,3-DPG value. Further studies with larger sample size in different types of surgeries and devices are needed to confirm these outcomes and to provide a basis for the safe use of salvaged RBCs in the clinical setting.

\section{Conclusions}

In summary, this study had shown that the oxygen transport function of salvaged RBCs at $0 \mathrm{~h}$ was not influenced by the cell salvage process and was better than that of the venous RBCs and 2-week-old packed RBCs. At the end of storage, the oxygen transport function of salvaged RBCs did not change obviously, but percentage of hemolysis significantly increased.

\section{Competing interests}

The authors declare that they have no competing interests.

\section{Authors' contributions}

JXN had the concept, XLL designed and set up the study with supervision from JXN and FGS. XLL, MT and PD obtained the consents, collected all the samples and undertook the measurements. XLL completed analysing the data with statistical support from a statistician and drafted the manuscript. FGS was chiefly responsible for the acquisition and interpretation of data and for finalising the manuscript. JXN, FGS and PD also were involved in critical review of the manuscript. XLL completed revision after submission. All authors read and approved the final manuscript.

\section{Acknowledgement}

Thanks to all the surgeons, anaesthetists, nursing staff and technicians for their help with data collection and sample analysis. Thanks to all the patients who willingly donated blood samples and contributed the data.

\section{Funding}

The project were supported by Beijing Medicine Research and Development Fundation(No.2007-1039), Beijing Natural Science Foundation(No.7122050) and Beijing Friendship Hospital Science Foundation (No.yyqdkt2011-25).

\section{Author details}

${ }^{1}$ Department of Pain Management, Xuanwu Hospital of Capital Medical University, No. 45, Changchun Street, Xicheng District, 100053 Beijing, China. 2Department of Anaesthesiology, Beijing Friendship Hospital, Capital Medical University, No. 95, Yong'an Road, Xicheng District, 100050 Beijing, China. ${ }^{3}$ Department of Anaesthesiology, the 2nd Affiliated Hospital \& Yuying Children Hospital of Wenzhou Medical University, Wenzhou, China. ${ }^{4}$ Perioperative, Critical Care and Trauma Trials Group, University of Birmingham, Edgbaston B15 2WB, Birmingham, UK.

Received: 27 February 2015 Accepted: 8 September 2015 Published online: 14 October 2015

\section{References}

1. Kuduvalli M, Oo AY, Newall N, Grayson AD, Jackson M, Desmond MJ, et al. Effect of peri-operative red blood cell transfusion on 30-day and 1-year mortality following coronary artery bypass surgery. Eur J Cardiothorac Surg. 2005:27:592-8.

2. Koch CG, Li L, Duncan Al, Mihaljevic T, Loop FD, Starr NJ, et al. Transfusion in coronary artery bypass grafting is associated with reduced long-term survival. Ann Thorac Surg. 2006;81:1650-7.

3. Surgenor SD, DeFoe GR, Fillinger MP, Likosky DS, Groom RC, Clark C, et al. Intraoperative red blood cell transfusion during coronary artery bypass graft surgery increases the risk of postoperative low-output heart failure. Circulation. 2006;114:143-8.

4. McGill N, O'Shaughnessy D, Pickering R, Herbertson M, Gill R. Mechanical methods of reducing blood transfusion in cardiac surgery: randomised controlled trial. BMJ. 2002;324:1299.

5. Vonk AB, Meesters MI, Garnier RP, Romijn JW, van Barneveld L, Heymans $M W$, et al. Intraoperative cell salvage is associated with reduced postoperative blood loss and transfusion requirements in cardiac surgery: a cohort study. Transfusion. 2013;53:2782-9. 
6. Huet C, Salmi LR, Fergusson D, Koopman-van GA, Rubens F, Laupacis A. A meta-analysis of the effectiveness of cell salvage to minimize perioperative allogeneic blood transfusion in cardiac and orthopedic surgery. International Study of Perioperative Transfusion (ISPOT) Investigators. Anesth Analg. 1999;89:861-9.

7. Phillips SD, Maguire D, Deshpande R, Muiesan P, Bowles MJ, Rela M, et al. A prospective study investigating the cost effectiveness of intraoperative blood salvage during liver transplantation. Transplantation. 2006;81:536-40.

8. Liang $H$, Zhao $Y$, Wang D, Wang B. Evaluation of the quality of processed blood salvaged during craniotomy. Surg Neurol. 2009;71:74-80.

9. Haidas S, Labie D, Kaplan JC. 2,3-diphosphoglycerate content and oxygen affinity as a function of red cell age in normal individuals. Blood. 1971:38:463-7.

10. Bunn HF, May MH, Kocholaty WF, Shields CE. Hemoglobin function in stored blood. J Clin Invest. 1969:48:311-21.

11. Sullivan IJ, Faulds JN. Lactate dehydrogenase and Haemolysis Index as quality control markers of haemolysis in intra-operative cell salvage. Transfus Med. 2013;23:326-9.

12. Janz DR, Bastarache JA, Peterson JF, Sills G, Wickersham N, May AK, et al. Association between cell-free hemoglobin, acetaminophen, and mortality in patients with sepsis: an observational study. Crit Care Med. 2013;41:784-90.

13. Vermeulen WI, Snoeijs MG, Hanssen SJ, Altintas S, Heijmans JH, Koeppel TA, et al. Hemolysis is associated with acute kidney injury during major aortic surgery. Kidney Int. 2010;77:913-20.

14. Klodell CT, Richardson JD, Bergamini TM, Spain DA. Does cell-saver blood administration and free hemoglobin load cause renal dysfunction? Am Surg. 2001;67:44-7.

15. Miller RD, Eriksson LI, Fleisher L, Wiener-Kronish JP, Young WL. Miller' Anesthesia. Churchill Livingstone; Expert Consult Premium ed of 7 th revised ed. 1951

16. Farrokhyar F, Wang $X$, Kent R, Lamy A. Early mortality from off-pump and on-pump coronary bypass surgery in Canada: a comparison of the STS and the EuroSCORE risk prediction algorithms. Can J Cardiol. 2007;23:879-83.

17. Wang $X$, Ji B, Zhang Y, Zhu X, Liu J, Long C, et al. Comparison of the effects of three cell saver devices on erythrocyte function during cardiopulmonary bypass procedure-a pilot study. Artif Organs. 2012;36:931-5.

18. Howdieshell TR, Gay M, DiPiro JT, Mooney S, Duvall R, Eckles S, et al. Heparin versus citrate regional anticoagulation during autotransfusion in a porcine intra-abdominal hemorrhage model. Am Surg. 1997;63:1014-8.

19. Dong P, Che J, Li X, Tian M, Smith FG. Quick biochemical markers for assessment of quality control of intraoperative cell salvage: a prospective observational study. J Cardiothorac Surg. 2014;9:86.

20. Che J, Tian M, Ding G, Huai Q, Dong P, Li Y, et al. Effects of cell salvage on erythrocyte 2,3-disphosphoglycerate and G-6-PD levels and phosphatidylserine expression. Int J Lab Hematol. 2013;35:385-92.

21. Opdahl H, Stromme TA, Jorgensen L, Bajelan L, Heier HE. The acidosisinduced right shift of the $\mathrm{HbO}(2)$ dissociation curve is maintained during erythrocyte storage. Scand J Clin Lab Invest. 2011;71:314-21.

22. Severinghaus JW. Blood gas calculator. J Appl Physiol. 1966;21:1108-16.

23. Samaja M, Mosca A, Luzzana M, Rossi-Bernardi L, Winslow RM. Equations and nomogram for the relationship of human blood p50 to 2,3 diphosphoglycerate, CO2, and H+. Clin Chem. 1981;27:1856-61.

24. Young RJ, Rachal RE, Del PAM, Nelson BL, Kim BC, Winter WP, et al. Automated oxyhemoglobin dissociation curve construction to assess sickle cell anemia therapy. J Natl Med Assoc. 2000;92:430-5.

25. Murphy GJ, Allen SM, Unsworth-White J, Lewis CT, Dalrymple-Hay MJ. Safety and efficacy of perioperative cell salvage and autotransfusion after coronary artery bypass grafting: a randomized trial. Ann Thorac Surg. 2004;77:1553-9.

26. Tylman M, Bengtson JP, Bengtsson A. Activation of the complement system by different autologous transfusion devices: an in vitro study. Transfusion. 2003:43:395-9

27. Gu YJ, Vermeijden WJ, de Vries AJ, Hagenaars JA, Graaff R, van Oeveren W. Influence of mechanical cell salvage on red blood cell aggregation, deformability, and 2,3-diphosphoglycerate in patients undergoing cardiac surgery with cardiopulmonary bypass. Ann Thorac Surg. 2008:86:1570-5.

28. Bordiuk JM, McKenna PJ, Giannelli SJ, Ayres SM. Alterations in 2-3 diphosphoglycerate and $\mathrm{O} 2$ hemoglobin affinity in patients undergoing open-heart surgery. Circulation. 1971;43:1141-6.

29. Young JA, Lichtman MA, Cohen J. Reduced red cell 2,3-diphosphoglycerate and adenosine triphosphate, hypophosphatemia, and increased hemoglobinoxygen affinity after cardiac surgery. Circulation. 1973;47:1313-8.
30. Bennett-Guerrero E, Veldman TH, Doctor A, Telen MJ, Ortel TL, Reid TS, et al. Evolution of adverse changes in stored RBCs. Proc Natl Acad Sci U S A. 2007;104:17063-8.

31. Latham JJ, Bove JR, Weirich FL. Chemical and hematologic changes in stored CPDA-1 blood. Transfusion. 1982;22:158-9.

32. Stan A, Zsigmond $E$. The restoration in vivo of 2, 3-diphosphoglycerate (2, 3-DPG) in stored red cells, after transfusion. The levels of red cells 2, 3-DPG. Rom J Intern Med. 2009:47:173-7.

33. Zallen G, Offner PJ, Moore EE, Blackwell J, Ciesla DJ, Gabriel J, et al. Age of transfused blood is an independent risk factor for postinjury multiple organ failure. Am J Surg. 1999;178:570-2.

34. Taylor RW, Manganaro L, O'Brien J, Trottier SJ, Parkar N, Veremakis C. Impact of allogenic packed red blood cell transfusion on nosocomial infection rates in the critically ill patient. Crit Care Med. 2002;30:2249-54.

35. Ciesla DJ, Moore EE, Johnson JL, Burch JM, Cothren CC, Sauaia A. A 12-year prospective study of postinjury multiple organ failure: has anything changed? Arch Surg. 2005;140:432-8. 438-40.

36. Carless PA, Henry DA, Moxey AJ, O'Connell D, Brown T, Fergusson DA. Cell salvage for minimising perioperative allogeneic blood transfusion. Cochrane Database Syst Rev. 2010;D1888(3).

37. Sowemimo-Coker SO. Red blood cell hemolysis during processing. Transfus Med Rev. 2002;16:46-60.

38. Donadee C, Raat NJ, Kanias T, Tejero J, Lee JS, Kelley EE, et al. Nitric oxide scavenging by red blood cell microparticles and cell-free hemoglobin as a mechanism for the red cell storage lesion. Circulation. 2011;124:465-76.

39. Gueye PM, Bertrand F, Duportail G, Lessinger JM. Extracellular haemoglobin, oxidative stress and quality of red blood cells relative to perioperative blood salvage. Clin Chem Lab Med. 2010;48:677-83.

40. Golab HD, Scohy TV, de Jong PL, Takkenberg JJ, Bogers AJ. Intraoperative cell salvage in infants undergoing elective cardiac surgery: a prospective trial. Eur J Cardiothorac Surg. 2008;34:354-9.

41. Cholette JM, Powers KS, Alfieris GM, Angona R, Henrichs KF, Masel D, et al. Transfusion of cell saver salvaged blood in neonates and infants undergoing open heart surgery significantly reduces RBC and coagulant product transfusions and donor exposures: results of a prospective, randomized, clinical trial. Pediatr Crit Care Med. 2013;14:137-47.

42. Yu B, Shahid M, Egorina EM, Sovershaev MA, Raher MJ, Lei C, et al. Endothelial dysfunction enhances vasoconstriction due to scavenging of nitric oxide by a hemoglobin-based oxygen carrier. Anesthesiology. 2010;112:586-94.

43. Yu B, Lei C, Baron DM, Steinbicker AU, Bloch KD, Zapol WM. Diabetes augments and inhaled nitric oxide prevents the adverse hemodynamic effects of transfusing syngeneic stored blood in mice. Transfusion. 2012;52:1410-22.

44. Spain DA, Miller FB, Bergamini TM, Montgomery RC, Richardson JD. Quality assessment of intraoperative blood salvage and autotransfusion. Am Surg. 1997;63:1059-63. 1063-4

\section{Submit your next manuscript to BioMed Central and take full advantage of:}

- Convenient online submission

- Thorough peer review

- No space constraints or color figure charges

- Immediate publication on acceptance

- Inclusion in PubMed, CAS, Scopus and Google Scholar

- Research which is freely available for redistribution

Submit your manuscript at www.biomedcentral.com/submit 